\title{
EU Accession to the ECHR Requires Ensuring the Franchise for EU Citizens in National Elections
}

\author{
Andrew Duff
}

As rapporteur of the European Parliament on electoral reform, I strongly support the launching of this ECI, and will sign it.

Another hopeful event is the prospect of the EU signing up to the ECHR (and its First Protocol). This will, in my view, allow disenfranchised citizens to seek a remedy at the European Court of Justice at Luxembourg and/or the European Court of Human Rights at Strasbourg by demanding that the EU now has a duty to act to guarantee 'conditions which will ensure the free expression of the opinion of the people in the choice of the legislature'.

With that in mind, I recently asked a written question of the European Commission as follows:

'All member states have adopted the first Protocol to the European Convention on Human Rights (ECHR), Article 3 of which states that: "The High Contracting Parties undertake to hold free elections at reasonable intervals by secret ballot, under conditions which will ensure the free expression of the opinion of the people in the choice of the legislature".

'In view of the imminent likely accession of the European Union to the ECHR and to its first Protocol, what does the Commission intend to do about member states who disenfranchise their own nationals who choose to live in another EU state for an extended period?

'Likewise, what does it intend to do to encourage EU states to extend the right to vote in national elections to their long-term resident EU citizens of another nationality?

'Does the Commission agree that it is unacceptable that a very large number of EU citizens are deprived of their basic civic right to choose the legislature either of the state in which they live or in their original state?

'Will the Commission be ready to take action to ensure that all EU states comply with the provisions of the ECHR which guarantee the right to vote?'

The answer of Commission Vice-President Reding (E-9269/2011, 2 February 2011) was somewhat disappointing. Here it is:

'As already highlighted in its reply to written question E-7910/2010 by Mr. Jim Higgins and E-8488/2011 by Mr. Morten Løkkegaard, the Commission is aware that national provisions in a number of member states disenfranchise 
their nationals due to their residence abroad. Consequently, EU citizens of the member states concerned cannot participate in any national elections.

'The Commission announced in the EU Citizenship report 2010 report (COM (2010)603) that it would launch a discussion to identify political options to prevent EU citizens from losing their political rights, and namely the right to vote in national elections, as a consequence of exercising their right to free movement. The Commission has recently contacted the concerned member states to launch this debate and to explore the possible political solutions.

'The Commission has raised at this occasion that, while organisation of national elections falls within the responsibilities of member states, if citizens cannot participate in electing member states government, nor in their member state of origin or the member state of residence, and thus are not represented in the Council of Ministers, these citizens cannot fully participate in the democratic life of the Union.

'The Commission would like to inform that the accession to the ECHR will not extend the European Union competences as defined in the Treaties. In particular, the accession to the First Protocol of the Convention neither will extend the right to vote of EU citizens residing outside their member state to national parliamentary elections, nor enable Commission to take actions against Member states' violations of Article 3 of this Protocol.'

The point about citizens not being able to 'vote' for their representatives in the Council of Ministers is interesting enough. Furthermore, although the Commission is bound to stick to the letter of the law, the fact is that once the EU signs up to the ECHR the rights prescribed in Articles 39 and 40 of the EU Charter of Fundamental Rights concerning voting and standing in local and European elections will not be as comprehensive as the citizen rightly demands. So wider legal and political action will surely be necessary at the EU level. And changes to both the primary and secondary law of the EU cannot be obstructed forever.

Open Access This chapter is licensed under the terms of the Creative Commons Attribution 4.0 International License (http://creativecommons.org/licenses/by/4.0/), which permits use, sharing, adaptation, distribution and reproduction in any medium or format, as long as you give appropriate credit to the original author(s) and the source, provide a link to the Creative Commons license and indicate if changes were made.

The images or other third party material in this chapter are included in the chapter's Creative Commons license, unless indicated otherwise in a credit line to the material. If material is not included in the chapter's Creative Commons license and your intended use is not permitted by statutory regulation or exceeds the permitted use, you will need to obtain permission directly from the copyright holder.

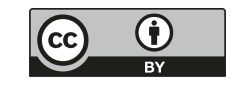

